\section{Discussion}

In adults prostatic calcification is often found in association with prostatic hypertrophy. Fox ${ }^{1}$ reviewed 3510 patients who had been examined radiologically and found that $484(13.8 \%)$ had prostatic calculi, the youngest patient being 16 years.

The history of rickets in this patient for which unknown amounts of vitamin D and calcium had been given might explain the prostatic calcification, as this is most unusual in so young a patient. The child was symptom-free when he came to our surgical unit and there was no sign of back pressure from either the prostatic calcification or the ureteric stone. Whether this boy will have any future complications from his prostatic calcification remains to be seen.

I thank Dr Modhafer Saeed for referring the patient, and Dr Issam Al-Hatem for performing the radiology.

\section{Reference \\ 1 Fox M. The association of stones in the upper urinary tract with prostatic calculi. Br J Urol 1960; 32: 458-63.}

Correspondence to A Y Izzidien FRCS, Department of Surgery, Medical College, Ninevah, Iraq.

\title{
Late presentation of vitamin D-dependent rickets
}

\author{
JENNIFER COWEN AND F HARRIS
}

\section{Department of Child Health, Alder Hey Children's Hospital, Liverpool}

SUMMARY An $8 \frac{1}{2}$-year-old girl presented with rickets. This had developed despite a normal diet and in the absence of symptoms, signs, or laboratory evidence of malabsorption, hepatic or renal disease. The rickets healed with physiological doses of $1-\alpha$-hydroxy-cholecalciferol. It is suggested that this case provides evidence for genetic and metabolic heterogeneity in vitamin D-dependent rickets.

Vitamin D-dependent rickets (pseudo deficiency rickets) is a rare but well recognised inborn error of cholecalciferol $\left(\mathrm{D}_{3}\right)$ metabolism, which presents classically in the first year of life. Prader et al ${ }^{1}$ were the first to describe infants with muscular hypotonia, retarded growth and development, hypocalcaemic tetany, and severe rickets. Such patients have low concentrations of serum calcium, low or normal serum inorganic phosphate, raised serum alkaline phosphatase, high serum parathormone, and a generalised aminoaciduria. The underlying defect is thought to be an inability in the kidney to achieve hydroxylation of $25(\mathrm{OH})$ cholecalciferol to 1,25 $(\mathrm{OH})_{2}$ cholecalciferol. This is inherited as an autosomal recessive. Recently it has been suggested that the condition is heterogeneous and that there may be more than one defect in the metabolism of $25(\mathrm{OH}) \mathrm{D}_{3}$ to $1,25(\mathrm{OH})_{2} \quad \mathrm{D}_{3}$ and its subsequent action on the gut. The patient reported here presented relatively late and lends some support to the latter hypothesis.

\section{Case report}

This $8 \frac{1}{2}$-year-old white girl presented with a short history of fever, paraesthesia in her fingers, and tetany. No other symptoms were elicited. Her diet was normal. Her past medical history was normal, except for gross obesity in infancy. Weights recorded at the local welfare clinic include $10.5 \mathrm{~kg}$ at $4 \frac{1}{2}$ months, $14 \mathrm{~kg}$ at 10 months, and $16.4 \mathrm{~kg}$ at 16 months. The diet consisted of full cream Cow and Gate milk at 5 months and a good mixed diet thereafter. On examination she was febrile, with a red throat, and cervical lymphadenopathy. She exhibited carpopedal spasm but Chvostek's sign was negative. There was no clinical evidence of rickets, enamel hypoplasia, or muscle hypotonia. She was above the 50th centile for height and the 90th centile for weight. Her father is 188 and her mother 156.7 $\mathrm{cm}$ tall. No other abnormality could be detected.

Her tetany responded rapidly to $20 \mathrm{ml}$ of $10 \%$ calcium gluconate given intravenously. Blood was then taken for analysis (Table). Her urine chromatogram showed gross generalised aminoaciduria. She showed no proteinuria or glycosuria. $X$-ray films of the left wrist and hand showed active rickets, with no evidence of hyperparathyroidism.

Further investigation did not show any biochemical evidence of malabsorption, nor any sign of renal or hepatic disease (Table). The patient was started on 10000 units of calciferol BP and $8 \mathrm{~g}$ calcium gluconate daily (Figure). She remained asymptomatic.

After 3 weeks of treatment her serum calcium was $2.09 \mathrm{mmol} / \mathrm{l}(8.4 \mathrm{mg} / 100 \mathrm{ml})$ and her serum inorganic phosphate $2 \cdot 02 \mathrm{mmol} / 1(6 \cdot 1 \mathrm{mg} / 100 \mathrm{ml})$. The aminoaciduria had resolved and $x$-ray films showed some bone healing. The calciferol was stopped and her biochemistry promptly deteriorated. 

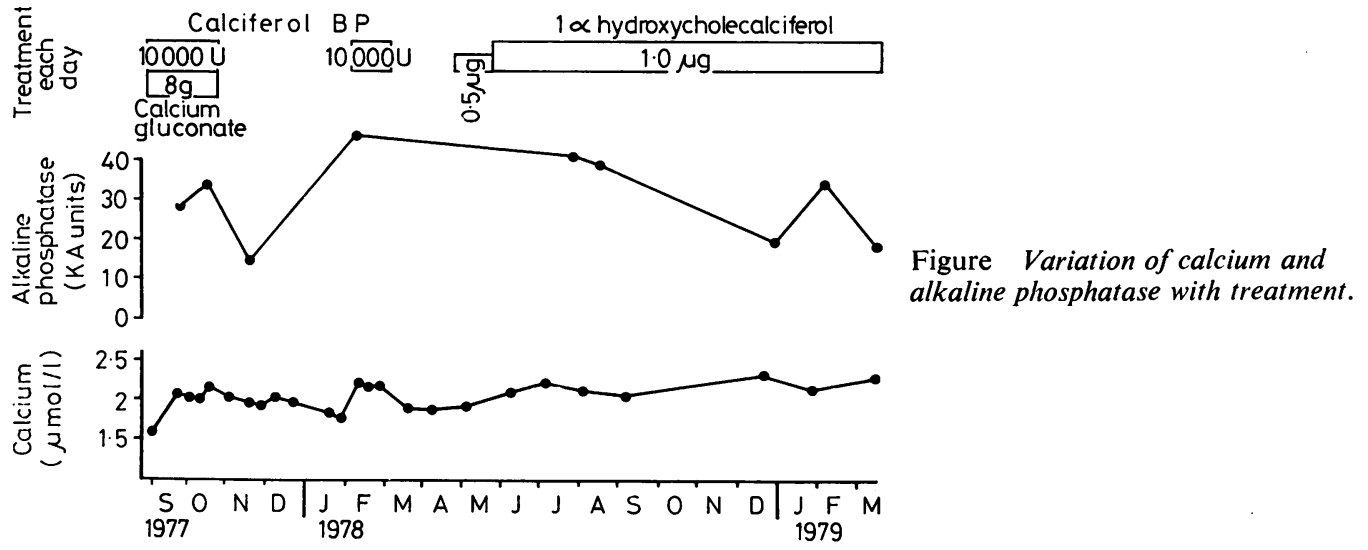

Table Results of some investigations

\begin{tabular}{|c|c|c|}
\hline & Patient & Normal \\
\hline \multicolumn{3}{|l|}{ Serum } \\
\hline Calcium & $1.6 \mathrm{mmol} / \mathrm{l}$ & \\
\hline Phosphate & $1.7 \mathrm{mmol} / \mathrm{l}$ & $1.1-1.9 \mathrm{mmol} / \mathrm{l}$ \\
\hline Alkaline phosphatase & 28 KA units & \\
\hline Magnesium & $0.80 \mathrm{mmol} / \mathrm{l}$ & \\
\hline Serum parathormone & $5 \mathrm{ng} / \mathrm{cm}^{3}$ & Less than $1.0 \mathrm{ng} / \mathrm{cm}^{3}$ \\
\hline 25-Hydroxy-vitamin D3 & $14 \cdot 1 \mathrm{ng} / \mathrm{ml}$ & $4-20 \mathrm{ng} / \mathrm{ml}$ \\
\hline Haemoglobin & $12.9 \mathrm{~g} / \mathrm{dl}$ & \\
\hline Urea and electrolytes & Normal & \\
\hline Plasma bicarbonate & $24 \mathrm{mmol} / 1$ & \\
\hline Serum creatinine & $70 \mu \mathrm{mol} / \mathrm{l}$ & \\
\hline Total serum protein & $68 \mathrm{~g} / 1$ & \\
\hline Albumin & $43 \mathrm{~g} / 1$ & \\
\hline \multirow{2}{*}{\multicolumn{3}{|c|}{$\begin{array}{l}\text { Serum aspartate } \\
\text { transaminase }\end{array}$}} \\
\hline & Less than $10 \mathrm{IU} / \mathrm{l}$ & \\
\hline \\
\hline \multicolumn{3}{|l|}{$\begin{array}{l}\text { tolerance tests } \\
\text { Blood gases (finger prick) }\end{array}$} \\
\hline $\mathrm{pH}$ & $7 \cdot 37$ & \\
\hline $\mathrm{PCO}_{2}$ & $41 \mathrm{mmHg}$ & \\
\hline Base excess & $-1 \mathrm{mmol} / \mathrm{l}$ & \\
\hline Standard bicarbonate & $23 \mathrm{mmol} / \mathrm{l}$ & \\
\hline Urine osmolality & $409 \mathrm{mmol} / \mathrm{kg}$ & \\
\hline Midstream urine & No growth & \\
\hline
\end{tabular}

Conversion: SI to traditional units - calcium $1 \mathrm{mmol} / 1 \approx 4 \mathrm{mg} / 100 \mathrm{ml}$, phosphate $1 \mathrm{mmol} / 1 \approx 3.09 \mathrm{mg} / 100 \mathrm{ml}$, magnesium $1 \mathrm{mmol} / 1 \approx 2.4$ $\mathrm{mg} / 100 \mathrm{ml}$, creatinine $1 \mu \mathrm{mol} / \mathrm{l} \approx 0.0113 \mathrm{mg} / 100 \mathrm{ml}$.

Within a month her calcium had fallen to 1.89 $\mathrm{mmol} / 1(7 \cdot 5 \mathrm{mg} / 100 \mathrm{ml})$ with a corresponding rise of her alkaline phosphatase to $43 \mathrm{KA}$ units. Four days after restarting calciferol 10000 units a day, after a 3-month period without any treatment, her 25 $(\mathrm{OH}) \mathrm{D}_{3}$ was $163 \mathrm{ng} / \mathrm{ml}$ and her parathormone $10 \mathrm{ng} / \mathrm{cm}^{3}$ Calciferol 10000 units per day was continued. After one month of treatment there was again an improvement in her serum calcium to $2 \cdot 3 \mathrm{mmol} / \mathrm{l}(9 \cdot 2 \mathrm{mg} / 100 \mathrm{ml})$. The calciferol was withdrawn once more and during the next 2 months the child's calcium fell to $1 \cdot 79 \mathrm{mmol} / \mathrm{l}(7 \cdot 2 \mathrm{mg} / 100$ $\mathrm{ml})$. At this time her plasma parathormone was $10 \mathrm{ng} / \mathrm{cm}^{3}$, and her plasma $25(\mathrm{OH})$ cholecalciferol was $51.0 \mathrm{ng} / \mathrm{ml}$, both above the upper limit of the normal range. The patient was started on $0.5 \mu \mathrm{g}$
1- $x$-hydroxy-cholecalciferol (one-alpha, Leo) daily. This dose was subsequently increased to $1 \mu \mathrm{g}$ daily. She has been on this treatment for 11 months and has remained well with normal biochemistry. There is no radiological evidence of rickets. Recent investigations show serum calcium $2 \cdot 38 \mathrm{mmol} / \mathrm{l}(9 \cdot 5 \mathrm{mg} / 100 \mathrm{ml})$, phosphate $1.96 \mathrm{mmol} / \mathrm{l}(6.0 \mathrm{mg} / 100 \mathrm{ml})$, and alkaline phosphatase $26 \mathrm{KA}$ units. Her urinary amino-acid pattern is normal. Serum parathormone was $1.7 \mathrm{ng} / \mathrm{ml}$, measured after 5 months' treatment with $1 \mu \mathrm{g} 1$ - $\alpha$-hydroxy-cholecalciferol.

\section{Discussion}

The history, biochemistry, and clinical course of this child show that her rickets was not due to nutritional deficiency of vitamin $\mathrm{D}$, malabsorption, or to chronic renal or hepatic disease. Although coeliac disease and other malabsorption states cannot be ruled out without further investigation, it is felt that these tests were not indicated in the face of such evident wellbeing, growth, and development. Furthermore, the child's response to an oral physiological dose of $1 \alpha$-hydroxycholecalciferol provides good evidence against these conditions. She lacks the features essential for familial hypophosphataemic rickets. Thus the most likely diagnosis is a mild variant of vitamin D-dependent rickets. It has been suggested that the primary defect is a failure of $1 \%$ hydroxylation of 25 $\mathrm{OH} \mathrm{D}_{3}$ in the kidneys, so such patients should respond to large doses of calciferol or to physiological doses of $1,25(\mathrm{OH})_{2} \mathrm{D}_{3}$. However, heterogeneity of the condition has been suggested by the variable response of 3 patients to dihydrotachysterol. ${ }^{2}$ One child responded well to dihydrotachysterol but 2 others, who were brothers, did not respond at all. Consequently it was concluded that all patients with this syndrome did not necessarily have the same autosomal recessive trait and 'that the 
metabolic block is differential and variable'. Balsan et al. ${ }^{3}$ thought that the slightly greater requirement of patients with vitamin D-dependent rickets for $1 \alpha$-hydroxy $D_{3}$ compared with vitamin D-deficient patients threw some doubt on the site and type of the metabolic block in the former condition. They suggested that this might be due to factors related to the severity of 25 hydroxy $D_{3} 1$ - $\alpha$-hydroxylase deficiency.

In infants of similar age and size Balsan et al. ${ }^{4}$ reported a range of dosage requirements of cholecalciferol $\left(D_{3}\right)$ from 600 to $7660 \mu \mathrm{g}$ daily. Although most patients with vitamin D-dependent rickets who have been described so far have required large doses of cholecalciferol, Rosen and Finberg ${ }^{2}$ mentioned one child who was maintained on 1000 IU/24hours $(20 \mu \mathrm{g}) 25-\mathrm{OH} \mathrm{D}$. $_{\text {. }}$.

It might be expected that if the defect were less severe the presentation of affected patients would be later, and this is borne out to some extent in the reports. The majority of patients who have been reported were between 1 month and 2 years when they first came to medical attention and they have required up to $100000 \mathrm{IU}(2.5 \mathrm{mg}) \mathrm{D}_{3}$ daily. The patient of Rosen and Finberg, ${ }^{2}$ who required 3500 IU $(87.5 \mu \mathrm{g}) \mathrm{D}_{3}$ daily, did not present until he was aged $4 \frac{1}{2}$ years when his main symptom was clumsiness. An even older patient (14 years) in that series was investigated because he was the sibling of an affected infant. He was maintained on a relatively small dose of $5000 \mathrm{IU}(100 \mu \mathrm{g}) 25-\mathrm{OH} \mathrm{D} \mathrm{D}_{3}$ daily.

It would seem that our patient has relatively mild disease and therefore presented late. Nevertheless, in common with more severely affected individuals she requires the physiological dose of $1 \mu \mathrm{g} 1$ - $\alpha$-hydroxycholecalciferol daily.

\section{References \\ 1 Prader A, Illig R, Heierli E. Eine besondere Form der primären Vitamin D resistenten Rachitis mit Hypocal- cämie und autosomal dominantem Erbgang: die hereditare Pseudo-Mangelrachitis. Helv Paediatr Acta 1961; 16: 452-68. \\ 2 Rosen J F, Finberg L. Vitamin D-dependent rickets: action of parathyroid hormone and 25 hydroxychole- calciferol. Pediatr Res 1972; 6: 552-62. \\ 3 Balsan S, Garabedian M, Sorgniard R, Holick M F, De Luca H F. $1 \propto$ hydroxy vitamin D: a comparative study in children. In: Bickel H, Stern J, eds. Inborn errors of calcium and bone metabolism. Lancaster: MTP Press, 1976: 179-90. \\ 4 Balsan S, Garabedian M, Courtecuisse V, et al. Long- term therapy with $1 \propto$ hydroxyvitamin $D_{3}$ in children with 'pseudo-deficiency' rickets. Clin Endocrinol [Oxf] (Suppl) 1977; 7 : 225-30S.}

Correspondence to Dr Jennifer Cowen, Department of Child Health, Alder Hey Children's Hospital, Eaton Road, Liverpool L12 2AP.

\title{
Zinc-dependent chemotactic defect in an infant with acrodermatitis
}

\author{
L BUSINCO, A M MENGHI, P ROSSI, R D'AMELIO, AND E GALLI \\ First Department of Paediatrics and Second Department of Infectious Diseases, University of Rome
}

SUMMARY A 5-month-old infant developed acrodermatitis enteropathica when weaned from breast milk to cows' milk. Plasma zinc concentration was low. T- and B-lymphocyte functions were normal, but there was a severe defect of neutrophil chemotaxis. Oral treatment with zinc sulphate (40 mg daily) induced an immediate clinical improvement, with restoration of normal plasma zinc level and complete correction of neutrophil chemotaxis.

Acrodermatitis enteropathica (AE) is an autosomal recessive inherited disorder characterised by diarrhoea, failure to thrive, anorexia, a vesiculobullous eruption around the mouth, anus, hands, and feet, alopecia, photophobia, paronychia, and high susceptibility to Candida albicans and Pseudomonas aeruginosa infections. The disease can appear when the infant is weaned from breast milk to cows' milk. In the untreated child death results from overwhelming infections, superimposed on a chronic marasmic state. Until a few years ago treatment was empirical, and consisted of breast-milk feeds and the oral administration of halogen-substituted 8hydroxy-quinolines. ${ }^{1}$ In 1975 Moynahan $^{2}$ reported low levels of zinc in the plasma of AE patients and the successful treatment of the disorder with oral zinc salts, which brought about both an increase in the plasma zinc and clearance of symptoms. Eckhert et al. ${ }^{3}$ suggested that the disorder might be related to zinc metabolism, with low quantities of certain zinc-binding ligands of low molecular weight, which are essential for the absorption of the metal, and protect it from chelation by other dietary components. The immune system of affected children has shown various anomalies: delayed-hypersensitivity skin reactions negativity, lack of serum IgA and IgM and, more recently, neutrophil and monocyte chemotaxis defect. ${ }^{4-6}$

We report an infant with $\mathrm{AE}$ who also had a severe neutrophil chemotaxis defect in the presence of normal intrinsic motile capacity. A striking 